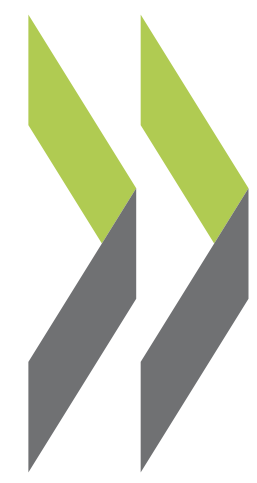

PEB Exchange, Programme on Educational Building 2007/11

\author{
Jenni Webster, \\ Leigh Robinson, \\ Kelvin Trimper, \\ Stan Salagaras
}

Sustainability Actions

in Australia

https://dx.doi.org/10.1787/072065184712 


\section{Sustainability Actions in Australia}

By Jenni Webster, Spowers Architects Facility and Development Advisors; Leigh Robinson, Taylor Robinson Architects; Kelvin Trimper, Lend Lease Communities; and Stan Salagaras, Mawson Lakes Development, Australia

Presented here are Australian case studies of educational buildings with environmentally sustainable designs - an upper secondary school complex and a university learning centre - and sustainability initiatives by a private developer working in collaboration with government authorities.

\section{WILLIAMSTOWN HIGH SCHOOL, BAYVIEW STREET CAMPUS, WILLIAMSTOWN, VICTORIA}

The new public school complex for Williamstown High School has been designed as a model for environmental education. The architects' aim was to incorporate sound environmental design principles with well-tested technologies to create an innovative design that could be constructed within a tight budget and lead the way for future public schools in Victoria.

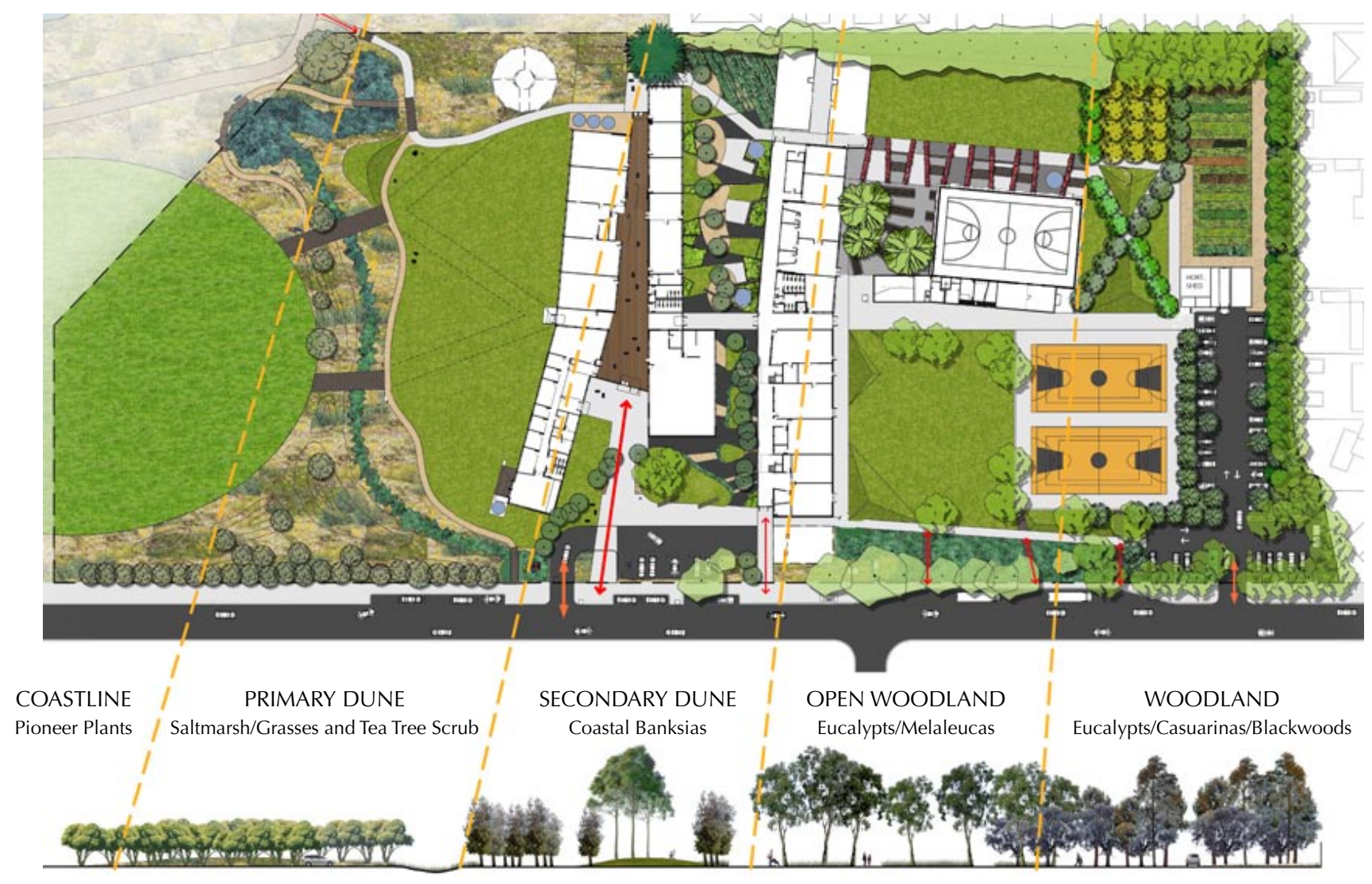


The recently completely school complex accommodates up to 750 students aged from 12 to 14 years and 50 staff. It consists of four buildings (two teaching blocks, a gymnasium and a horticulture facility) totaling 5300 square metres on a suburban coastal site with magnificent access to and views of Port Philip Bay and the Jawbone Marine Sanctuary.

The buildings are fully naturally ventilated (no airconditioning) with high level louvres and thermal chimneys for night purging of the internal air during the summer months. Other environmental features include reverse (recycled) brick veneer walls, high performance single glazing, hollowcore concrete plank construction, rainwater collection that is used for toilet flushing and irrigation, solar hot water, recycling of existing materials such as the timber floor in the atrium, minimisation of PVC, low offgassing materials and finishes, and low energy light fittings.

The school is currently serving as a pilot project for the Green Star Education rating tool developed by the Green Building Council of Australia.

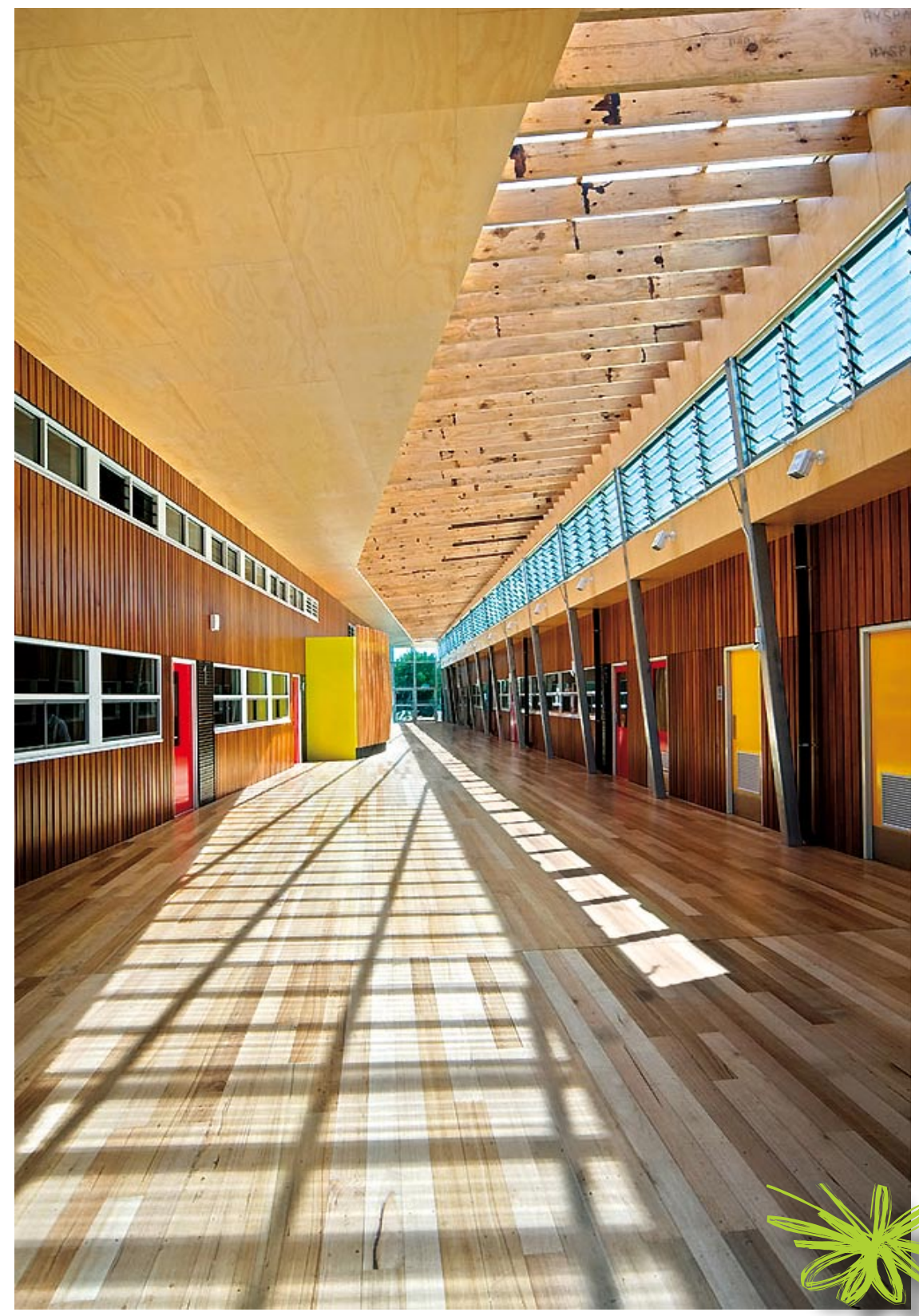

For more information, contact: Jenni Webster

Senior Project Architect

Spowers Architects Facility and Development Advisors Level 3120 King Street Melbourne, Victoria Tel.: 61396146144 E-mail: jenniw@spowers.com.au www.spowers.com.au 


\section{MURDOCH UNIVERSITY - PEEL LEARNING CENTRE}

The Peel Learning Centre was designed to incorporate a number of environmentally sustainable development initiatives. It was the first building designed for Murdoch University on the Peel Education Campus, in Mandurah, Western Australia. The AUD 3.5 million facility, initially designed to accommodate the Faculty of Nursing, was completed in 2005.

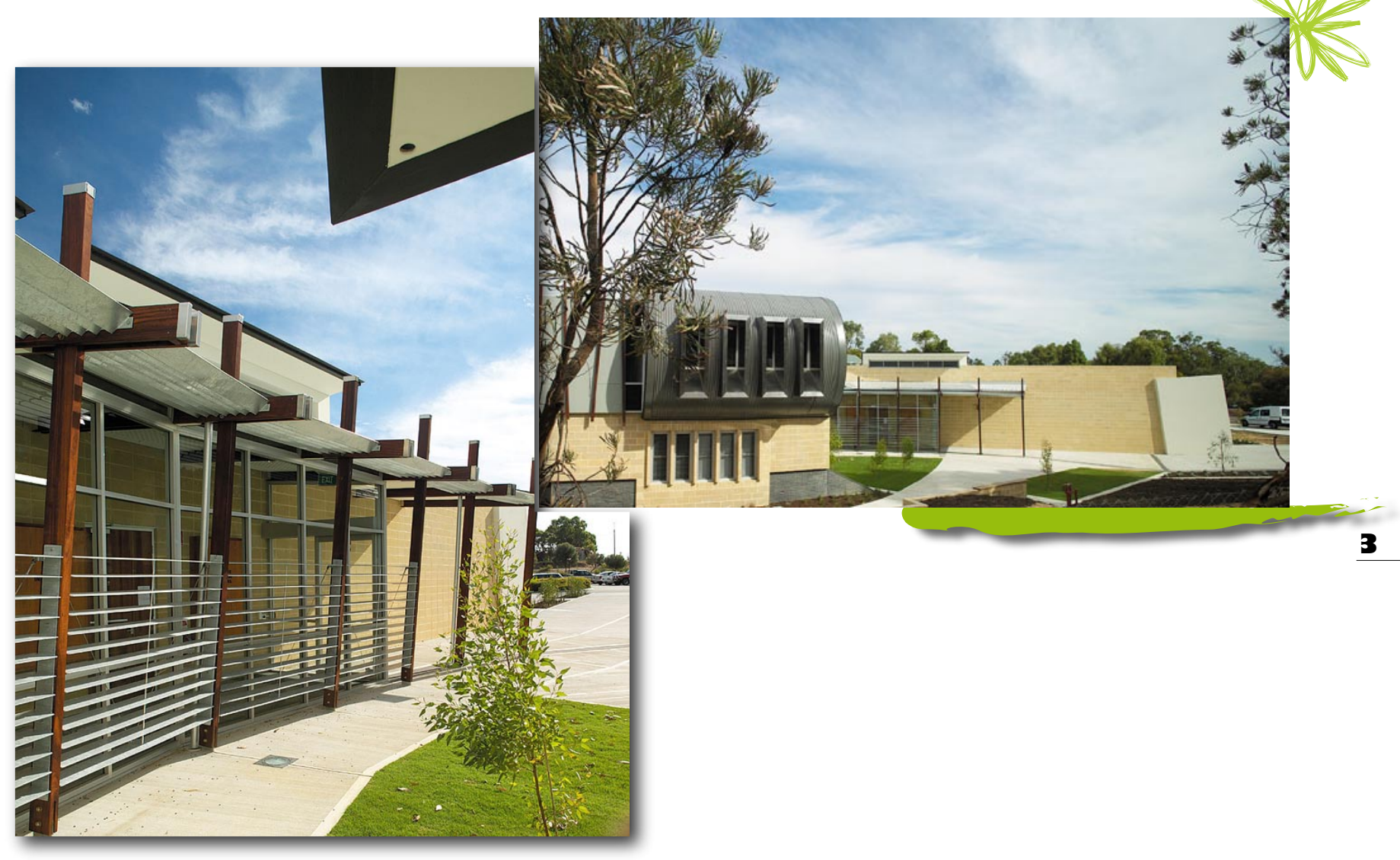

The building responds directly to the client's brief for an iconic structure that clearly sign-posted the university as a modern and progressive learning institution. It is positioned along the northern edge of the existing campus, which also is home to a senior college for Year 11 and 12 students (ages 16 to 18) and a Technical and Further Education (TAFE) facility for post-compulsory students.

The building incorporates a range of environmental and energy efficiency initiatives.

The northern orientation permits the concrete filled blockwork, thermal main storage walls to be heated during the winter months. The stored heat is then re-radiated into adjoining lecture rooms. The glazed walkways are shielded from the heat of the summer sun by a galvanized steel vertical sunscreen.

Night purging of the internal ground floor lecture room and computer laboratories is controlled by the building management system via a system of low- and high-level glazed louvres, which renews the building's air over night during the hot summer months.

Materials with a low embodied energy have been selected where practical. External block walls are made of aerated concrete in lieu of clay. The main structural supports for the enclosed walkway spine are made of local recycled jarrah hardwood. The backing to the carpet tiles has a high recycled material content. 
All external walls are fully insulated with polyester wall batts in the lightweight walls and polystyrene foam in the cavities of the blockwork walls.

The building management system controls the air-conditioning. The mechanical ventilation is set to operate only when the internal temperature rises above the pre-set mark. Gas space heaters heat the lecture and computer spaces. A roof mounted weather station connected to the building management system allows the university's main Perth campus to monitor local weather conditions and temperatures in Mandurah and to track the building's performance.

For more information, contact:

Leigh Robinson

Taylor Robinson Architects

234 Railway Parade, West Leederville

Western Australia 6007

Tel.: 61893886111

E-mail: swise@tayrob.com.au

www.taylorrobinson.com.au

\section{SUSTAINABILITY INITIATIVES BY PRIVATE DEVELOPERS}

Progressive urban development companies are working in partnership with local, state and national government authorities to create and maintain sustainable communities and contribute to environmentally sustainable development. These communities provide education for people of all ages, ranging from stand-alone schools to integrated provision for lifelong learning.

Many governments are experiencing significant pressure arising from migration, population shift and the subsequent demand for release of land for housing and the provision of schools, health and welfare services, recreation and community facilities, and public transport. Collaboration between private developers and government authorities is a key component in innovative and progressive urban planning, leading to sustainable communities and environmentally sustainable homes, recreation areas and workplaces.

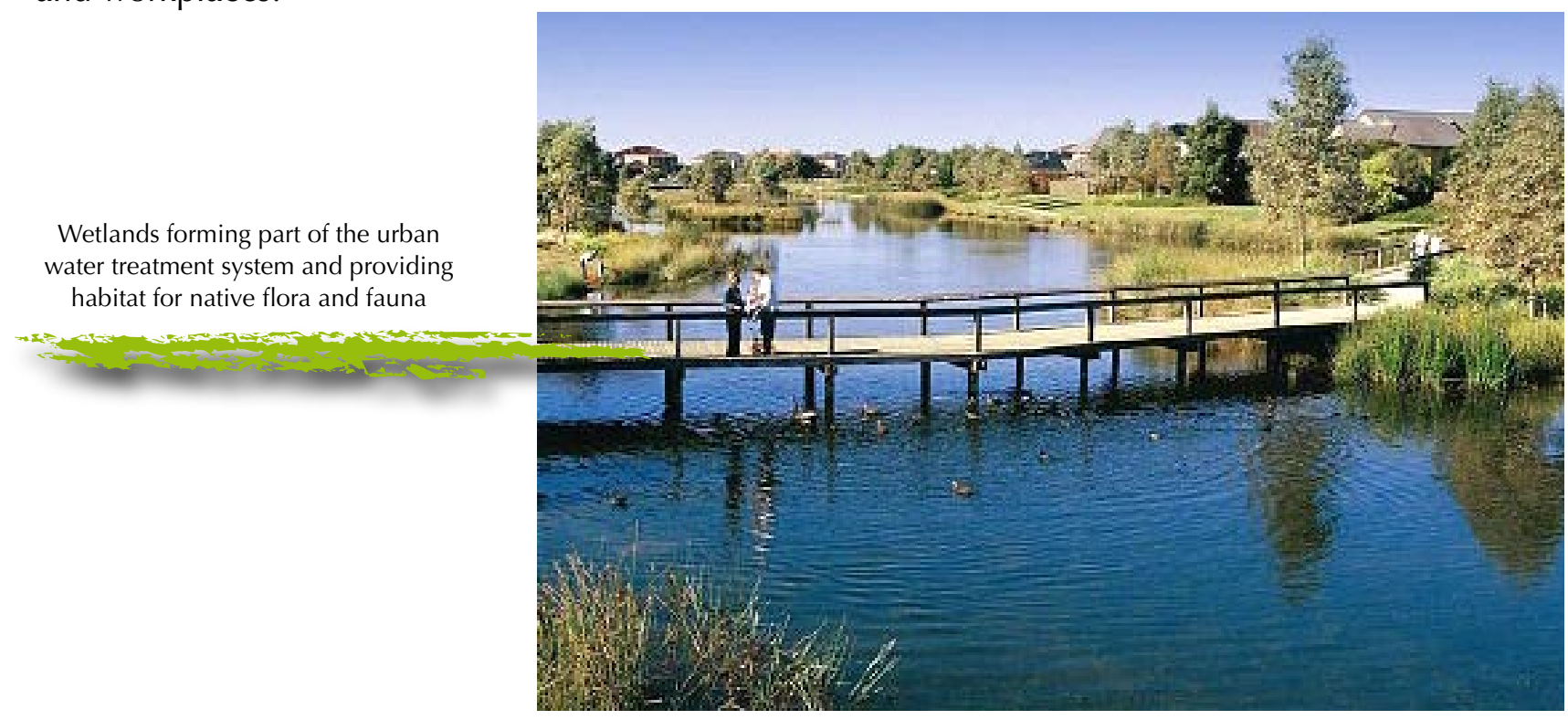




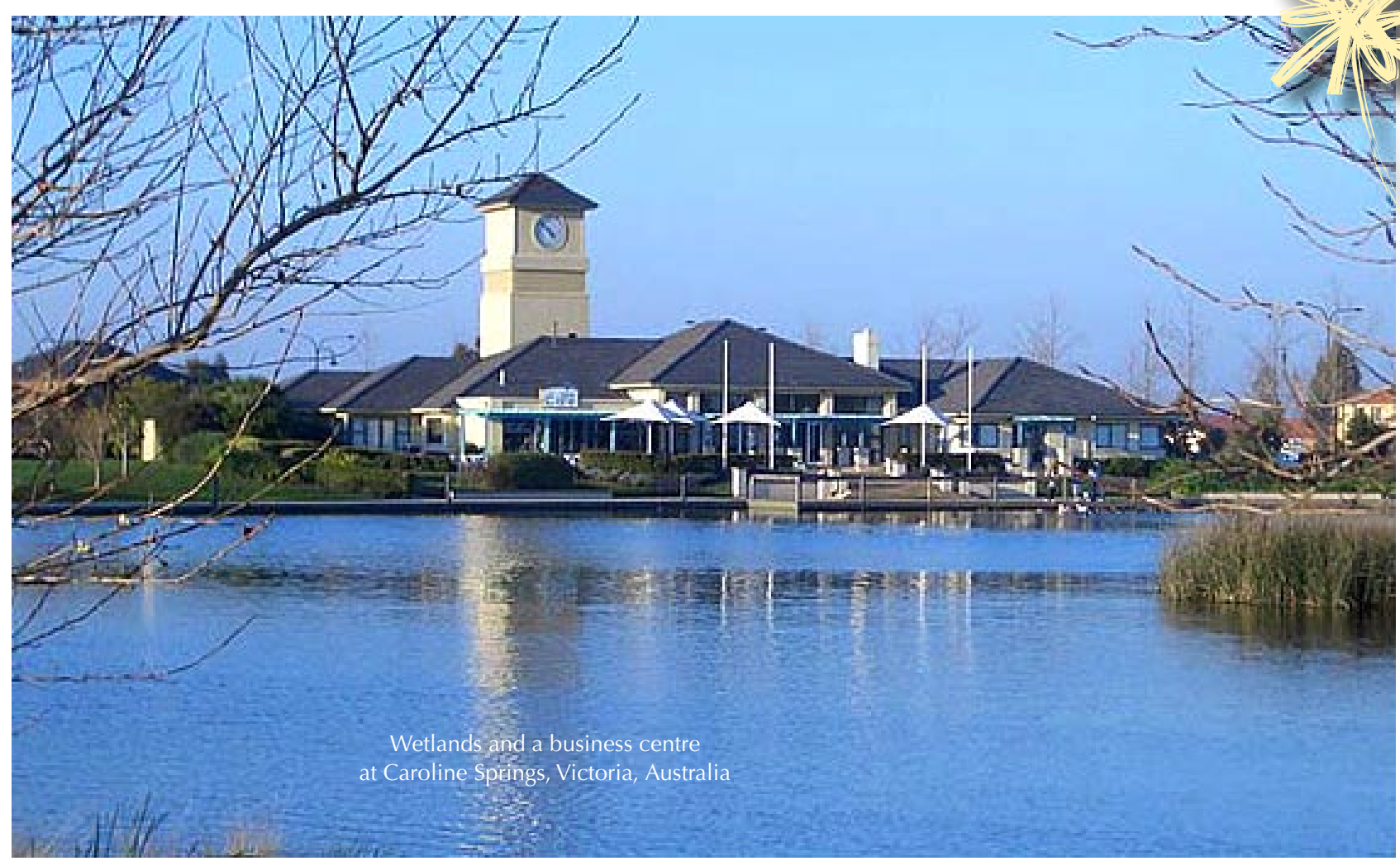

Specific environmentally sustainable initiatives have been incorporated into new urban developments in Australia, as well as South East Asia, the United Kingdom and the United States, by Lend Lease, an international urban community and commercial development company. The company works in partnership with local, state and national government authorities and construction management businesses to create sustainable communities which successfully balance environmental, social and economic outcomes. It builds communities that respect and enhance the natural environment and that provide sustainable environmental practice. Similar developments have been undertaken by local authorities working in partnership with urban developers in Canada, Ireland and New Zealand.

\section{Sustainable landscapes... a commitment to the environment}

Standard landscaping practices in many developments tend to be unsustainable, so action has been taken to implement a variety of innovative and genuinely sustainable measures, including landscapes which reflect local conditions and water supplies, plantings and water treatments which enrich the environment and increase biodiversity, and multi-usage landscapes with enhanced aesthetic appeal and designs which respond to community needs and encourage community ownership and interaction. The local community, including students from the local schools, is actively involved in selecting, planting and maintaining landscaped areas.

\section{Water... turning the tap on innovation}

There is a strong and growing understanding about the need to protect our natural resources. Increasing recognition about the scarcity of fresh water reserves (potable supplies) means adopting sensible water conservation and usage practices. A number of initiatives have been taken relating to the treatment of waste water and stormwater management, water conservation incorporating wetland development and aquifer recharging, the use of potable and recycled water, smart landscaping practices and water sensitive 
urban designs, as well as student and community education programmes. These initiatives demonstrate that it is possible for communities to reduce water usage and still create beautiful landscaped parks and gardens, with green open spaces and waterside living. It also provides an opportunity to involve students in the planning, monitoring and use of features such as wetlands, lakes and lagoons, landscape management and water conservation programmes.

\section{Education... access for all}

The social, economic and environmental sustainability of communities depends on creating communities where a cross-section of people want to live, work and play. Delivery of innovative education services that provide for the continued learning and development of people of all ages is achieved through the creation of learning partnerships between private and public education providers, business and community organisations; the optimal use of new information and communication technologies to amplify, extend and transform the nature of learning; the development of flexible and shared community learning spaces; and the creation and ongoing development of a learning culture which continues to improve the community.

\section{Recreation and leisure... an essential part of life}

The development of recreation facilities and provision of leisure opportunities are integrally linked to other core community services including health, education and job creation. Commitment to and achievement in the planning and provision of recreation and leisure facilities, services, and programmes allow opportunities to incorporate environmentally sustainable development initiatives as an integral part of the services provided. The rehabilitation and retention of natural bushland offer recreation trails and landscaping that encourage interaction between community members, and a safe environment for young children enhances the quality of community life and the pursuit of outdoor recreation activities.

\section{Enhancing economic sustainability}

Enterprise and economic growth are central elements of sustainable and evolving communities. Environmentally sustainable development enhances property values and provides employment opportunities through a wide range of occupations in areas such as research, training, retail, construction, and maintenance and management of the environment and associated services.

For more information, contact:

Kelvin Trimper

General Manager, Sustainability Initiatives

Lend Lease Communities

Mawson Lakes, South Australia 5095

Tel.: 61883605432

E-mail: kelvin.trimper@lendlease.com.au

Stan Salagaras

Manager, Education Services

Mawson Lakes Development

Tel.: 61883439718

E-mail: stansal@ozemail.com.au

www.lendlease.com.au 


\section{ORGANISATION FOR ECONOMIC CO-OPERATION AND DEVELOPMENT}

The OECD is a unique forum where the governments of 30 democracies work together to address the economic, social and environmental challenges of globalisation. The OECD is also at the forefront of efforts to understand and to help governments respond to new developments and concerns, such as corporate governance, the information economy and the challenges of an ageing population. The Organisation provides a setting where governments can compare policy experiences, seek answers to common problems, identify good practice and work to co-ordinate domestic and international policies.

The OECD member countries are: Australia, Austria, Belgium, Canada, the Czech Republic, Denmark, Finland, France, Germany, Greece, Hungary, Iceland, Ireland, Italy, Japan, Korea, Luxembourg, Mexico, the Netherlands, New Zealand, Norway, Poland, Portugal, the Slovak Republic, Spain, Sweden, Switzerland, Turkey, the United Kingdom and the United States. The Commission of the European Communities takes part in the work of the OECD.

OECD Publishing disseminates widely the results of the Organisation's statistics gathering and research on economic, social and environmental issues, as well as the conventions, guidelines and standards agreed by its members.

This work is published on the responsibility of the Secretary-General of the OECD. The opinions expressed and arguments employed herein do not necessarily reflect the official views of the Organisation or of the governments of its member countries.

No reproduction, copy, transmission or translation of this publication may be made without written permission. Applications should be sent to OECD Publishing rights@oecd.org or by fax 331452499 30. Permission to photocopy a portion of this work should be addressed to the Centre français d'exploitation du droit de copie (CFC), 20, rue des Grands-Augustins, 75006 Paris, France, fax 331463467 19, contact@cfcopies.com or (for US only) to Copyright Clearance Center (CCC), 222 Rosewood Drive Danvers, MA 01923, USA, fax 1978646 8600, info@copyright.com. 